In this Issue

Editorial

TARIQ KHAN. \title{
Translation Today
}

An Overview: Children's Literature, Its Development and Translation in China MIN GAO

.....1

- Indian Anuvād or English Translation? Combining Tradition and Modernity in the Nationalistic Translations of Nineteenth Century Bengal

SASWATI SAHA

- Colonial Politics of Finding Equivalence: Interpreting 'Translation' and Anubad through Nineteenth Century English to Sanskrit/Bengali Dictionaries

RINDON KUNDU

- Shakespeare in Gujarati: A Translation History

SUNIL SAGAR

- The Self and the Other: Some Reflections on Self-Translation IRFAN AHMAD DAR

- Pańchopākhyāna: Fossilized Marathi Culture and the Translation Lens PRIYADA SRIDHAR PADHYE

\section{Book Reviews}

- Working with Different Text Types in English and Arabic: Translation in Practice

RAMESH M. INGALE

- Moving Texts, Migrating People and Minority Language

MEENU SABU

- Screening the Author: The Literary Biopic GIRISH N

\section{Annotated Bibliographies}

- An Annotated Bibliography of Translation Studies Books Published in 2018: Part II

RANDHEER KOUR

- An Annotated Bibliography of the Translation Studies Books Published in 2019: Part I

SUBHA CHAKRABURTTY

Translation

- Gachak Andharee by Ashok Mankar \& Deenu's Bill by Prahlad Keshav Atre

UMESH KUMAR

Contributors

Volume 13, Issue 2, 2019

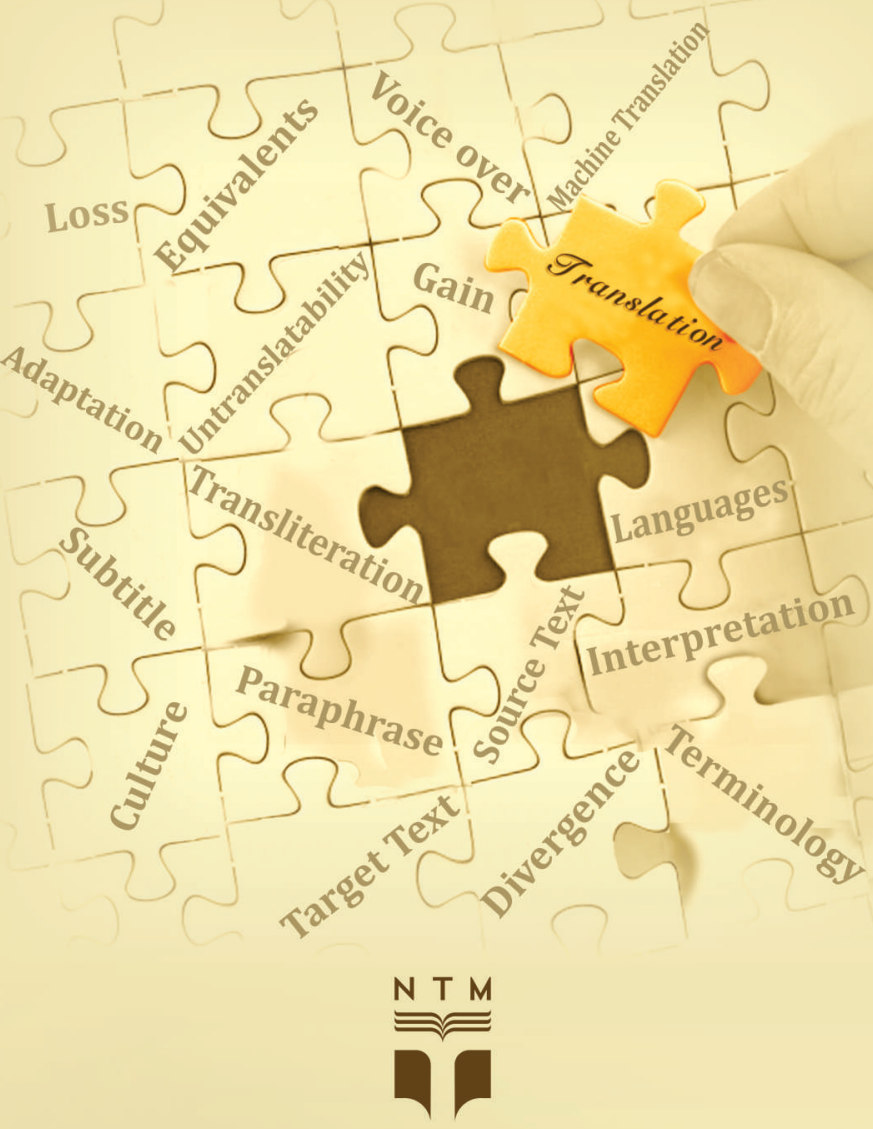

राष्ट्रीय अनुवाद मिशन

NATIONAL TRANSLATION MISSION

CENTRAL INSTITUTE OF INDIAN LANGUAGES 


\section{Publication Policy}

Translation Today (TT) is a double-blind peer-reviewed, indexed and refereed journal of the National Translation Mission (NTM). This has been listed in the UGC approved list of journals. It follows the standard publishing norms and therefore, invites original and unpublished submissions in the following categories:
- Research articles
- Academicinterviews
- Disciplinary dialogues
- Translations
- Book reviews
- Annotated bibliography

\section{Vision}

- Seeks a spurt in translation activity

- Seeks excellence in the translated word.

- Seeks to further the frontiers of Translation Studies.

- Seeks to raise a strong awareness about translation, its possibilities and potentialities, its undoubted place in the history of ideas, and thus help catalyse a groundswell of well-founded ideas about translation among people.

\section{Submission}

Translation Today welcomes submissions in the following areas (but not limited to): Annotated and original translations of all literary genres, translated excerpts from novels are accepted where they stand on their own, glossaries in any subject in any language-pair (Indian Languages TO Indian Languages or Indian Languages TO English or English TO Indian Languages), specialties in the translation profession: religious, technical, scientific, legal, commercial, specialities in the interpreting profession: court, conference, medical and community, multimedia, terminology, localization, translation technology: HAMT, translation memory softwares, translation teaching softwares, papers on translation as a category of or a significant dimension of thought, pieces relating translation to society, to culture, to philosophy, to poetics, to aesthetics, to epistemology, to ontology, to movements like feminism, subalternism, to power and so on, translation universals etc., to awarenesses like civilisational space, nationalism, identity, the self, the other and so on, on translation pedagogy, translation curriculum, translation syllabus etc., ethics, status, and future of the profession, translator-related issues, translator studies: legal, copyright issues etc., squibs and discussion notes which are short pieces throwing up an interesting problem or analytical puzzle, reviews of translated texts, dictionaries and softwares, letters to the Editor.

For submissions and queries, please write to:

\section{Project Director}

National Translation Mission,

Central Institute of Indian Languages,

Hunsur road, Manasagangotri, Mysuru-570006.

E-mail: projectdirector.ntm[AT]gmail[DOT]com, cc to:

ntmtranslationtoday[AT]gmail[DOT]com
Articles submitted for consideration of the Board will have to be in English. Translation Today will seriously consider the possibility of publishing material in Indian languages, or a multilingual edition of the journal in future. There is no size-limit on articles except that they may preferably be within $40 \mathrm{~K}$ to avoid slow downloading for the electronic version. Articles should, however, be preferably and optimally between 2000 and 3000 words in length for the print-based version. Unpublished contributions will be preferred. While submitting pieces already published elsewhere, the author must mention the fact as well as get permission to reproduce the same. The submission should be by e-mail. Please use .doc or .txt format. Graphics could be in JPEG, GIF, Photoshop or BMP format. All articles should carry a 100word abstract and a short bio-note of the contributor.

\section{Style and conventions}

The journal prefers American Psychological Association (APA) style/LSA style. Diagrams and figures should be suitable for photographic/scanner reproduction. Drawings should be in black font. Lettering should be of draughtsman standard and large enough to remain legible where the figure requires reduction in size. Tables should be typed on separate sheets.

\section{Author's Benefit}

All the contributors from India would receive a complimentary copy (print) of the journal and overseas contributors would receive an e-copy of the journal.

\section{Reviewing System}

The Translation Today follows double-blind peer-review policy. At first, the received paper is reviewed by the editors. If the editors find the paper suitable for the journal qualitatively, then the paper is sent to the experts who review the paper based on the guidelines of the Translation Today. The decision of accepting a paper for publication depends on the review report. Please see the Review Response Sheet in the NTM website.

\section{Publication Fee}

The Translation Today does not charge any processing or publication fees.

Copyrights

Copyrights for the articles/translations/book reviews are retained by the National Translation Mission, Central Institute of Indian Languages, Mysore.

\section{Plagiarism}

Though all submissions are put on rigorous plagiarism check, the responsibility of originality of content rests with the concerned authors. A paper found with plagiarized content (major or minor) will not be considered for reviewing or publication.

\section{Open Access Policy}

For the wider dissemination of knowledge, all published articles of the Translation Today are freely accessible online. The back volumes of the print edition are also available on payment.

\section{Disclaime}

The views expressed in the articles are solely that of the authors, and the editors or members of the Editorial Board are in no way responsible. 


\section{Translation Today}
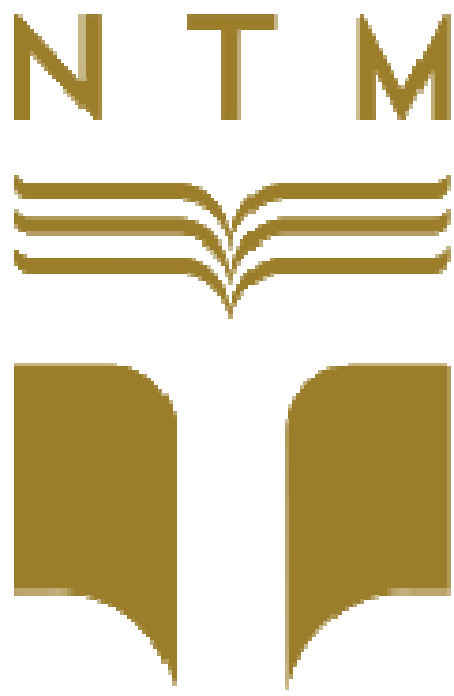

Editor

TARIQ KHAN

Volume 13, Issue 2

2019 


\section{Editor}

\section{TARIQ KHAN}

Officer in Charge, NTM

\section{Assistant Editors}

GEETHAKUMARY V., NTM, CIIL

Abdul Halim, NTM, CIIL

Aditya K. PANDA, NTM, CIIL

\section{Advisors}

D. G. RAO, Director, CIIL

C. V.SHIVARAMAKRISHNA

Head, Centre for TS, CIIL

\section{Editorial Board}

\section{SUSAN BASSNETT}

School of Modern Languages and Cultures, University of Warwick, Coventry, United Kingdom

\section{HARISH TRIVEDI}

Department of English, University of Delhi,

New Delhi, India

\section{Michael Cronin}

School of Applied Language and Intercultural Studies, Dublin

University, Dublin, Ireland

\section{DOUGLAS ROBINSON}

Department of English, Hong Kong Baptist University,

Kowloon Tong, Hong Kong

\section{SHERRY SIMON}

Department of French, Concordia University, Quebec, Canada

\section{JEREMY MUNDAY}

School of Languages, Cultures and Societies, University of Leeds, Leeds, United Kingdom

\section{ANTHONY PYM}

Translation and Intercultural Studies, The RoviraiVirgili University, Tarragona, Spain

\section{Panchanan Mohanty}

Centre for Applied Linguistics and Translation Studies, University of Hyderabad, Hyderabad, India

\section{Alain Desoulieres}

INALCO, France, Visiting Fellow Centre of French and Francophone Studies, JNU, New Delhi, India

\section{SUSHANT KUMAR MISHRA}

Centre of French and Francophone Studies, JNU, New Delhi, India

\section{MIKI NISHIOKA}

Graduate School of Language and Culture, Osaka University Osaka 565-0871, Japan

\section{LAKSHMI HARIBANDI}

Department of Translation Studies, The English and Foreign Languages University, Hyderabad, India 


\section{Translation Today}

Volume 13, Issue 2, 2019

Web Address: http://www.ntm.org.in/languages/english/translationtoday.aspx

\section{Editor: TARIQ KHAN}

E-mail: ntmtranslationtoday@gmail.com / projectdirector.ntm@gmail.com

(C) National Translation Mission, CIIL, Mysuru, 2019.

This material may not be reproduced or transmitted, either in part or in full, in any form or by any means, electronic, or mechanical, including photocopy, recording or any information storage and retrieval system, without permission in writing from:

\section{Director}

Central Institute of Indian Languages, Manasagangotri, Hunsur Road, Mysuru - 570 006, INDIA

Phone: 0821-2515006 (Director)

E-mail: director@ciil.org

Fax: 0821-2515032

director-ciil@gov.in

www.ntm.org.in

\section{For further information contact:}

Head, Publication Unit

Contact: 0821-2345026

Email:umarani@ciil.org umarani.psamy@gov.in
For Publication orders

Publication Unit

Ph: 0821-2345182, 09845565614

Email: nandeesh77@gmail.com

publication.kar-ciil@nic.in

\section{ISSN: 0972-8740}

e-ISSN: 0972-8090

\section{One Year Subscription: INR 500; US \$ 100: EURO 80; POUND 60}

Excluding postage (air-mail)

Published by

Head, Press \& Publication

Officer-in-Charge

Printing Supervision by Layout \& Cover Design

Printed at
: Prof. D. G. Rao, Director

: Prof. Umarani Pappuswamy, Prof-cum-Deputy Director

: Aleendra Brahma, Lecturer-cum-JRO

: R. Nandeesh, M. N. Chandrashekar \& H. Manohar

: Dr. Abdul Halim \& Nandakumar L

: CIIL, Printing Press, Mysuru 